\title{
Public Attention, Government Subsidies and Corporate Environmental Disclosure: Empirical Evidence from Listed Chinese Enterprises in Heavy-Pollution Industries
}

Qun Wang

Accounting Department, Tongling University, Tongling 244061, China

Corresponding Author Email: wangqun2006@tlu.edu.cn

https://doi.org/10.18280/ijsdp.150306

Received: 29 September 2019

Accepted: 15 December 2019

\section{Keywords:}

corporate environmental disclosure, media reports, government subsidies, government supervision, public attention

\begin{abstract}
Environmental pollution, a byproduct of industrialization, is increasingly severe across the globe. The effective control of environmental pollution requires enterprises to make highquality disclosure of environmental behaviors. This paper collects and processes the annual data of A-share listed enterprises in 16 heavy-pollution industries of China between 2016 and 2018, and empirically explores the relationship between public attention, government subsidies and environmental disclosure. The results show that the number of media reports, as an indicator of public attention, has a significantly positive impact on corporate environmental disclosure. In terms of media preference, positive reports stimulate enterprises to actively disclose environmental behaviors. When the other conditions are the same, the government subsidies received by an enterprise have a significantly positive impact on its environmental disclosure. The growth of government subsidies weakens the promoting effect of media reports on corporate environmental disclosure. The research findings provide new insights into the improvement of corporate environmental disclosure.
\end{abstract}

\section{INTRODUCTION}

In 2013, China suffered from the most severe haze in history, which thrusts carbon emissions and PM2.5 into the limelight. By the end of that year, PM2.5 testing systems began to operate in most cities of China. In the following year, the leader of the Chinese government pointed out at the APEC summit that, "Blue sky, green mountains and clear waters are essential to the Chinese dream." This means, with the soaring economy, the Chinese government and the public are attaching greater importance to environmental issues.

Being the major economic players in society, enterprises have exerted a growing impact on social resources and ecoenvironment, while creating economic values. This calls for stricter environmental regulation by the government. So far, the environment departments have put forward a series of policies, rules and regulations, aiming to promote and improve corporate environmental disclosure.

However, the current laws and regulations in China have made it mandatory for enterprises to disclose environmental behaviors only under a few circumstances. In most cases, enterprises are merely guided or encouraged to disclose such behaviors. The methods, contents and quantities of the disclosure are all at the discretion of enterprises. As a result, the disclosure level varies greatly from enterprise to enterprise.

Facing the severe environmental pollution in China, many scholars have highlighted the importance of the public in environmental supervision. You and Yang [1] recommended making tip-offs from the public an information source of government supervision, suggesting that the pressure from the public, coupled with that from the central government, will force local governments to strengthen environmental regulation. Zhang et al. [2] analyzed how the efficiency of industrial pollution control is affected by public supervision and policies on public participation in environmental protection. In reality, however, the public has a limited access to pollution control, and their weak power is not highly recognized.

Compared with the public, the news media can spread information timely across a wide region, and effectively shape the public opinion. The news reports on the environmental issues of the enterprises will pressurize the society and the government to concern themselves with these issues. Through empirical analysis, Li et al. [3] discovered that it is external pressure, rather than internal pressure, that determines how willing and how much the heavy-pollution industries in China disclose environmental behaviors. Due to their strong externalities, environmental issues cannot be effectively solved by the market. Enhanced government regulation is an important way to eliminate environmental externalities.

The stakeholder theory holds that enterprises will not disclose environmental behaviors in the absence of the pressure from major stakeholders, namely, the government, major customers, suppliers, competitors, communities, the public, and the media. Among them, the government can directly apply a huge pressure on enterprises. The pressures from the public and the media are also considerably large. The former formulates a series of laws and regulations to standard and guide the environmental behavior of enterprises, while the latter pressurizes the enterprises through public opinion or media reports.

In China, corporate environmental disclosure does not bode well. The managers have the discretion to decide whether and how to make the disclosure. Many enterprises only choose to disclose the behaviors required to be public by laws and regulations. The selective disclosure often excludes important 
or negative behaviors. Many enterprises manipulate their information superiority over the public (potential investors), and send positive signals to the society about their sustainability through selective disclosure. Then, the public will overestimate their environmental performance, and buy their stocks in large quantities.

Against this backdrop, there are two unanswered questions: Facing public attention and media supervision, will enterprises actively disclose environmental behaviors to maintain a positive social image? Besides issuing mandatory rules, could the government encourage corporate environmental disclosure through incentive measures like government subsidies? To answer these questions, this paper explores the correlations between public attention, government subsidies and corporate environmental disclosure, and tries to explain the relationship between the disclosure motives of enterprises and stakeholders The research findings enable enterprises to improve environmental disclosure and implement strategies of sustainable development, laying the basis for building an ecologically civilized country.

Based on the existing literature, this research mainly makes two major contributions. Firstly, this paper introduces new perspectives to the research into corporate environmental disclosure. The previous studies have focused on the passive disclosures, under the pressures from government regulation and negative media reports. Drawing on the signaling theory and stakeholder theory, this paper empirically verifies that positive incentives (e.g. government subsidies, public attention and media coverage) could encourage enterprises to actively disclose environmental behaviors.

Secondly, this paper probes deep into the impacts of report preference (positive, negative or neutral reports) on corporate environmental disclosure. With the growth in government regulation and environmental awareness of enterprises, there are fewer negative reports on environmental behaviors of enterprises. Our results show that corporate environmental disclosure can be promoted by positive reports, but suppressed by negative reports. By contrast, the previous research generally believes that negative reports spur on the disclosure of positive environmental behaviors.

The remainder of this paper is organized as follows: Section 2 introduces the relevant theories and literature, and proposes several hypotheses; Section 3 explains data processing, variable design and model construction; Section 4 presents and analyzes the empirical results; Section 5 makes further discussion about relevant issues; Section 6 puts forward the conclusions and some countermeasures.

\section{PRELIMINARIES}

\subsection{Public attention and corporate environmental disclosure}

The law of limited attention goes that investors, with limited time and energy, cannot acquire sufficient information in time, due to the sheer volume and fast changes of market information. Hence, an individual could only analyze the information that attracts his/her attention, and make judgement based on the information. The mass media will shape public thoughts and change public perception. Wen and Zhou [4] argued that all the public are obliged to protect the environment; without public participation, environmental issues cannot be solved efficiently, for the lack of responsible and supervisory entities

Carroll and McCombs [5] put forward several propositions about the relationship between the media and the public: (1) the number of media reports on an enterprise is positively correlated with the public attention to the enterprise; (2) the number of media reports on an aspect of an enterprise is positively correlated with the proportion of the public that judge the enterprises by the aspect; (3) the more positive the reports on an aspect of an enterprise, the more positive the public view on the aspect of the enterprise; the inverse is also true.

For the following reasons, this paper measures the degree of public attention by the number of media reports: the media provides enterprises with a disclosure channel; the media supervises the autonomy and management of enterprises; the frequency of reports plays the roles of information intermediary and public supervision.

Most of the existing studies agree that the number and preference of reports on environmental issues promote corporate environmental disclosure. Tzouvanas et al. [6] claimed that media coverage has a great impact on corporate environmental disclosure, and that negative reports spur on the disclosure of positive environmental behaviors. Yu et al. [7] demonstrated that, under media coverage and public attention, the enterprises suffering from major environmental accidents will disclose more environmental behaviors, such as to meet requirements on compliance. Shen and Feng [8] confirmed that the preference of reports on environmental performance significantly promotes corporate environmental disclosure, suggesting that the disclosure increases with the negativity of reports.

Through the above analysis, this paper proposes the following hypotheses:

H1a: The number of media reports has a significant impact on corporate environmental disclosure.

$\mathrm{H} 1 \mathrm{~b}$ : The preference of media reports has a significant impact on corporate environmental disclosure.

\subsection{Government subsidies and corporate environmental disclosure}

Government subsidies refer to the free transport payment provided by the government to enterprises, according to the political and economic principles and policies for the current period. Government subsidies could appear in the form of fiscal appropriations, fiscal discounts, tax incentives, and free allocation of non-monetary assets. Chinese officials are willing to issue government subsidies, because their performance is partly appraised against pollution indices like PM2.5, in the face of severe environmental problems.

Liu [9] held that corporate management will take economic and ecological benefits as the goals of environmental accounting, under the support of the government's environmental policies and industry policies. Overall, over half of polluting enterprises have received financial support from different government departments. These supports motivate enterprises to implement environmental governance and develop circular economy. To manage the environment, the government needs to step up its control over heavypollution enterprises.

Shi et al. [10] detailed the game between the government and enterprises, pointing out that politicians will allure enterprises to comply with political goals through subsidies and tax incentives. Considering economic principles and 
policies, government subsidies offer a means for local governments to promote investment and seek growth. At present, environmental governance has gradually become an important political goal. The government often resorts to capital subsidies or tax incentives to stimulate corporate environmental disclosure [11].

In the course of environmental management, the government actively intervenes in the business activities of enterprises, such as setting energy-saving standards, rewarding green techniques and eliminating outdated capacity. Government subsidies provide enterprises with the resources to upgrade their equipment and purchase green facilities. To obtain the preferential treatments, enterprises will ramp up investment in environmental protection, implement technical transformation, and actively disclose environmental behaviors in financial reports, social responsibility reports or special environmental reports. This will inevitably improve corporate environmental disclosure.

Through the above analysis, this paper proposes the following hypothesis:

H2: Government subsidies have a significantly positive impact on corporate environmental disclosure.

\subsection{Correlations between public attention, government subsidies and corporate environmental disclosure}

According to game theory and signaling theory, corporate environmental disclosure and media reports are the only ways for the public and the government to learn how enterprises treat and emit pollutants, owing to the information asymmetry. The Chinese public is highly concerned about environmental pollution, because their life and work are seriously affected by air and water pollutions, the side effects of industrialization and economic growth. In 2012, the US Embassy in Beijing released PM2.5 data, causing widespread public concern about environmental pollution. In 2015, China revised the Measures for Public Participation in Environmental Protection, which allows citizens to supervise the pollutant emissions by enterprises through whistleblower letters, reports and accusations, making environmental governance more efficient

The signaling theory indicates that government subsidies convey the information about the quality of enterprises. The public tends to believe that enterprises, which are subsidized by the government, have good prospects and reputations. The incentive measures (e.g. tax reduction, environmental subsidies and emission reduction reward) received by enterprises will be reported by the media. In this way, the public will get familiar with and think highly of the incentivized enterprises. To win government subsidies and social recognition, enterprises will willingly make highquality disclosure of environmental behaviors.

Government subsidies, coupled with public and media supervision, will create a number of benchmark enterprises. Other enterprises will imitate the environmental behaviors of benchmark enterprise, invest more in environmental protection, and actively disclose more environmental behaviors to the government and the public. Using an econometric model, $\mathrm{Li}$ and Ramanathan [12] noticed that government response promotes public participation, which, in return, stimulates the government to implement relevant works. Yang et al. [13] investigated the impacts of the government on corporate environmental disclosure, and drew the following conclusions: political relevance has a positive correlation with corporate environmental disclosure; political relevance and corporate environmental disclosure have an intermediary effect on political subsidies.

Nevertheless, the public attention is a double-edged sword. The enterprises receiving public attention may be hailed as role models and may be condemned and penalized. If the disclosed behaviors fall short of expectation, an enterprise will raise a higher degree of concern, and face a greater probability of being investigated and punished by the regulatory department. Sheng and Min [14] stated that, since corporate environmental disclosure is not yet a norm, most enterprises choose to disclose environmental behaviors in a conservative and low-pitched fashion: a greater disclosure attracts more attention, and increases the risk of penalties against violations. During the decision-making of environmental disclosure, the management will weigh between the chance of winning government subsidies and the risk of being penalized.

In addition, Ji et al. [15] learned that, with the increase of government regulation, the media's attention and supervision on enterprises decline, which weakens the influence of media reports on corporate environmental disclosure. Liu and Yang [16] constructed a game payment matrix based on evolutionary game theory, and summed up the relationship between media supervision and government regulation in view of the cost-benefit of reports: the media is reluctant to supervise the environmental behaviors of enterprises, when government regulation is strict; the media has a strong desire of supervision, when government regulation is relaxed. This means government regulation weakens the effects of media reports on corporate environmental disclosure.

Through the above analysis, this paper proposes two competing hypotheses:

$\mathrm{H} 3 \mathrm{a}$ : Government subsidies positively regulate the relationship between public attention and corporate environmental disclosure; the growth of government subsidies enhances the promoting effect of media reports on corporate environmental disclosure.

H3b: Government subsidies negatively regulate the relationship between public attention and corporate environmental disclosure; the growth of government subsidies weakens the promoting effect of media reports on corporate environmental disclosure.

\section{METHODOLOGY}

\subsection{Sampling and data sources}

Our samples were collected from the annual data of A-share listed enterprises in 16 heavy-pollution industries (thermal power, steel, cement, electrolytic aluminum, coal, metallurgy, chemicals, petrochemicals, building materials, papermaking, brewing, pharmaceuticals, fermentation, textiles, tanning, and mining) between 2016 and 2018. The original data were screened by the following criteria:

(1) Removing the stock data of special treatment (ST) enterprises, because the data of such enterprises usually have lots of anomalies;

(2) Removing the stock data of listed enterprises with abnormal transactions;

(3) Removing the samples with missing financial data and industry variables;

(4) Removing the enterprises with greater-than- $100 \%$ assetliability ratios, because such enterprises tend to be insolvent;

(5) Removing the enterprises with greater-than-150\% sales 
growth rate, because the surge in sales is often the result of mergers and acquisitions;

(6) Removing the enterprises listed after 2015.

To obtain robust results, the continuous variables on the enterprise level were winsorized at $1 \%$ and $99 \%$ levels, producing 1,143 samples. The financial data of all the enterprises were downloaded from China Stock Market \& Accounting Research Database (CSMAR) and Wind Database.

\subsection{Research design}

3.2.1 Explained variable: environmental disclosure index (EDI)

This paper relies on content analysis, the most important and popular research tool for social responsibility and environmental disclosure, to evaluate the EDI of the sample enterprises.

According to the Measures for Public Participation in Environmental Protection (Trial), China encourages enterprises to actively publicize nine kinds of environmental behaviors. On this basis, the environmental behaviors disclosed by the sample enterprises were divided into eight items, according to the features of annual reports of listed enterprises:

(1) Environmental investment and development of green technologies;

(2) Government grants, financial subsidies and tax reductions related to environmental protection;

(3) Pollutant emissions and emission reduction;

(4) ISO environmental certification;

(5) Measures to improve eco-environment;

(6) Impacts of the government's environmental policies;

(7) Loans related to environmental protection;

(8) Legal actions, compensations, fines and rewards related to environmental protection.

Next, the EDI of each enterprise was assessed and rated in terms of quantity and quality. The quantity score equals the number of items mentioned in the annual report. The quality score was rated in three dimensions, namely, significance, quantifiability and timeliness, drawing on the strategies of Plumlee et al. [17], Chen and Qian [18], Sengupta [19]:

\section{(1) Significance}

The annual report was divided into financial part and nonfinancial part. If the items are disclosed in the financial part only, 1 point will be assigned; if the items are disclosed in the non-financial part only, 2 points will be assigned; if the items are disclosed in both parts, 3 points will be assigned.

(2) Quantifiability

If the items are described in text, 1 point will be assigned; if the items are quantified but non-financial, 2 points will be assigned; if the items are financial, 3 points will be assigned.

(3) Timeliness

If the items are about the status quo, 1 point will be assigned; if the items are about the future, 2 points will be assigned; if the current and past items are compared, 3 points will be assigned.

Finally, the quality score and quantity score of each enterprise were normalized by z-score, and then added up into the EDI score of the enterprise.

\subsubsection{Explanatory variables: media reports and government subsidies}

Despite the prevalence of online news, this paper measures the degree of public attention of corporate environmental performance by the number of reports on print media. This is because important news on printed media must also appear online, and excel online news in credibility and quality.

Sixteen newspapers were selected for our research, including China Securities Journal, China Environment News, People's Daily, Guangming Daily, Securities Daily, Securities Times, Economic Daily, Shanghai Securities News, Financial News, China Economic Times, Business Times, China Business News, The Economic Observer, China Business Journal, Economic Information Daily, and $21^{\text {st }}$ Century Business Herald.

These influential newspapers have been widely recognized for their timely and high-quality reports. All of them are frequently used as data sources for media studies by scholars engaging in economics, management and business.

The authors searched for news reported by the above newspapers between 2016 and 2018 on the environmental behaviors of the sample enterprises in China Core Newspapers Full-Text Database (CCND). One point was assigned for each piece of news found. The points of each sample enterprise were added up into the total score of news reports on that enterprise.

In addition, this paper measures government subsidies of each sample enterprise by the total amount of government subsidies for environmental protection (including government grants, financial subsidies and tax reductions), which are sorted out by the CSMAR from the appendices of the annual report of each listed enterprise. Because the amount must be an absolute number, the subsidies of each sample enterprises were added up and then normalized by Z-score.

For accuracy, both news reports and government subsidies were winsorized at $1 \%$ and $99 \%$ levels, and then normalized by Z-score.

\subsubsection{Control variables}

According to the existing research, the relevant data on financial and governance structure of each sample enterprise was taken as control variables, including the return on equity (ROE), the asset-liability ratio (LEV), the size of enterprise (SIZE), the ownership property (State), the number of independent directors (IDR), and the education background of executives (BSS).

All the variables are explained in Table 1 below.

Table 1. Explanation of research variables

\begin{tabular}{cccc}
\hline Variable & Variable name & Notation & Calculations \\
\hline Explained variable & Environmental Disclosure & EDI & Total quantity and quality score of environmental disclosure \\
Explanatory variable & Media Reports & News & Number of paper media reports on environmental news of listed companies \\
Explanatory variable & Government Subsidies & Subsidy & Adjusted amounts of government subsidies \\
& Profitability & ROE & The return on equity \\
& Leverage & LEV & Total Assets divided by Total Liabilities \\
Control variable & Company Size & Size & Logarithm of total company assets \\
& Nature of Equity & State & State-owned-1, other- 0 \\
& Independent Director & IDR & Number of independent directors \\
& Executive Qualifications & BSS & Number of executives with master degree or above \\
\hline
\end{tabular}




\subsection{Model construction}

Inspired by Steven Cahan et al. [20] and Wang et al. [21], this paper sets up the following multiple regression models to examine how media reports and government subsidies on environmental protection influence corporate environmental disclosure, and how government subsidies affect media reports:

$$
\begin{gathered}
E D I_{i t}=\alpha+\beta_{1} \text { News }_{i t}+\sum \beta_{i} \text { Controls }_{i t}+\xi_{i t} \\
E D I_{i t}=\alpha+\beta_{2} \text { subsidy }_{i t}+\sum \beta_{i} \text { Controls }_{i t}+\xi_{i t} \\
E D I_{i t}=\alpha+\beta_{1} \text { News }_{i t}+\beta_{2} \text { subsidy }_{i t}+\beta_{3} \text { News }_{i t} \\
* \text { subsidy }_{i t}+\sum \beta_{i} \text { Controls }_{i t} \\
+\xi_{i t}
\end{gathered}
$$

where, $E D I$ is the index of corporate environmental disclosure; News is the number of reports on printed media on a listed enterprise; subsidy is the normalized total government subsidies on environmental protection received by a listed enterprise.

\section{EMPIRICAL RESULTS AND ANALYSIS}

\subsection{Descriptive analysis}

As shown in Table 2, the mean, minimum and maximum of the explained variable EDI were 7.57, 0 and 17, respectively. There is a significant difference between sample enterprises in the EDI. This means the listed enterprises in heavy-pollution industries differ greatly in environmental disclosure. The main reason is that only a few environmental behaviors are required to be disclosed in the current laws and regulations, leaving the enterprises a large discretionary power.

Table 2. Descriptive statistics on research variables

\begin{tabular}{ccccccccc}
\hline variable & mean & $\mathrm{p} 25$ & $\mathrm{p} 50$ & $\mathrm{p} 75$ & $\min$ & $\max$ & $\mathrm{sd}$ & $\mathrm{N}$ \\
\hline EDI & 7.570 & 4 & 7 & 11 & 0 & 17 & 4.130 & 1143 \\
News & 58.78 & 11.00 & 24.00 & 72.00 & 1.00 & 130 & 20.08 & 1143 \\
Subsidy & $2.9 \mathrm{e}+06$ & 0.00 & 0.00 & $6.4 \mathrm{e}+05$ & $-7.5 \mathrm{e}+06$ & $2.8 \mathrm{e}+08$ & $1.8 \mathrm{e}+07$ & 1143 \\
ROE & 0.0600 & 0.0300 & 0.0600 & 0.130 & -0.1482 & 0.2300 & 0.560 & 1143 \\
LEV & 0.430 & 0.270 & 0.420 & 0.580 & 0.0300 & 0.900 & 0.210 & 1143 \\
Size & 22.79 & 21.78 & 22.57 & 23.78 & 19.48 & 28.52 & 1.430 & 1143 \\
State & 0.480 & 0 & 0 & 1 & 0 & 1 & 0.500 & 1143 \\
IDR & 3.270 & 3 & 3 & 3 & 2 & 8 & 0.660 & 1143 \\
BSS & 6.610 & 5 & 6 & 8 & 2 & 12 & 2.410 & 1143 \\
\hline
\end{tabular}

The mean, minimum and maximum of the explanatory variable news reports were 58.78, 1 and 130, respectively, putting the standard deviation at 20.08. This means the listed enterprises in heavy-pollution industries have significant difference in media coverage and public attention.

The mean and maximum of the explanatory variable government subsidies were negative and $2.8 \mathrm{e}+08$, respectively, revealing a huge difference between sample enterprises. Therefore, some enterprises have been heavily subsidized by the government, while some have not received any subsidy, but paid environmental fines.

Finally, the mean, minimum and maximum of the control variable ROE were $6 \%,-14.82 \%$ and $23 \%$, respectively. The results demonstrate a clear disparity in profitability between the listed enterprises in heavy-pollution industries. With the growing awareness of environmental protection, heavypollution enterprises must pay high costs for treating the pollutants generated in the production process. The results highlight the importance of government subsidies.

\subsection{Multiple regression analysis}

The coefficient of the interaction term between government subsidies and media reports was estimated to be significantly negative at the $5 \%$ level. This shows government subsidies can regulate media reports to a certain extent, and weaken the relationship between media reports and corporate environmental disclosure. Hence, hypothesis $\mathrm{H} 3 \mathrm{~b}$ is proved valid.

In addition, the control variables SIZE and State exhibited significantly positive correlations with corporate environmental disclosure in all regressions. It can be seen that the environmental disclosure increases with the enterprise size; state-owned enterprises disclose environmental behaviors better than non-state-owned enterprises.

For any other control variable, the coefficient sign and significance remained stable in all regressions. This agrees with the results of the previous studies.

Table 3. Results of multiple regressions

\begin{tabular}{cccc}
\hline & Model (1) & Model (2) & Model (3) \\
\hline News & $0.0235^{* * *}$ & & $0.0247 * * *$ \\
& $(0.00294)$ & & $(0.00296)$ \\
Subsidy & & $0.238^{* * *}$ & 0.370 \\
& & $(0.0629)$ & $(0.0680)$ \\
News*Subsidy & & & $-0.00260^{* *}$ \\
& & & $(0.00116)$ \\
IDR & 0.0571 & -0.0353 & 0.0284 \\
& $(0.187)$ & $(0.197)$ & $(0.187)$ \\
BSS & -0.0421 & -0.0569 & -0.0586 \\
& $(0.0439)$ & $(0.0450)$ & $(0.0441)$ \\
ROE & -0.151 & $-0.316^{*}$ & $-0.411 *$ \\
& $(0.128)$ & $(0.146)$ & $(0.140)$ \\
LEV & 0.273 & -0.735 & -0.411 \\
& $(0.669)$ & $(0.708)$ & $(0.679)$ \\
Size & $0.926 * * *$ & $1.729^{* * *}$ & $1.096^{* * *}$ \\
& $(0.215)$ & $(0.225)$ & $(0.227)$ \\
State & $3.021 * * *$ & $1.943^{* * *}$ & $2.498^{* * *}$ \\
& $(0.760)$ & $(0.710)$ & $(0.759)$ \\
Constant & $-15.36^{* * *}$ & $-31.91 * * *$ & $-18.44 * * *$ \\
& $(4.823)$ & $(5.055)$ & $(5.067)$ \\
Observations & 1,143 & 1,143 & 1,143 \\
Number of ID & 381 & 381 & 381 \\
\hline The bracketed numbers are standard errors; *,** and *** are $<<0.1$, \\
$\mathrm{p}<0.05$, and $\mathrm{p}<0.01$, respectively.
\end{tabular}




\section{DISCUSSION}

To further disclose the impacts of media reports and government subsidies on corporate environmental disclosure, new reports were divided into three categories based on preference: positive reports (POS), neutral reports (NEU) and negative reports (NEG). The number of each type of reports was counted. The numbers of POS, NEU and NEG were normalized by Z-score, such that the models are distributed independently yet identically.

Meanwhile, the EDI was also classified into three types: overall EDI (Adj EDI), financial EDI (EDIF), and nonfinancial EDI (NEDIF). The Adj EDI was calculated in three steps: dividing the disclosed environmental behaviors into the above-mentioned eight items; assigning 1 point to each item if it is qualified and 2 points if it is qualified and quantified; adding up all the points of all items and taking the average value.

The EDIF equals the mean of the quantity scores on the following aspects of corporate environmental disclosure: (1) emergency expenditures for major environmental issues; (2) pollutant charge and environmental tax; (3) environmental investment or borrowings; (4) emission reduction benefits; (5) waste utilization income; (6) government subsidies.

Similarly, the NEDIF equals the mean of the quality scores on the following aspects of corporate environmental disclosure: (1) environmental disclosure system; (2) environmental management objectives; (3) environmental measures and improvement; (4) implementation of certifications; (5) energysaving measures and results; (6) compliance in the types and emissions of pollutants; (7) independent social responsibility report/ sustainable development report/ environmental report.

The descriptive statistics on the above variables are given in Table 4. On this basis, the following models were established for regression analysis:

$$
\begin{aligned}
& A d j_{-} E D I_{i t}=\alpha+\beta_{1} P O S_{i t}+\beta_{2} M E D_{i t}+\beta_{3} N E G_{i t}+\beta_{4} \text { subsidy }_{i t} \\
& +\sum \beta_{i} \text { Controls }_{i t}+\xi_{i t} \\
& E D I F_{i t}=\alpha+\beta_{1} P O S_{i t}+\beta_{2} M E D_{i t}+\beta_{3} N E G_{i t}+\beta_{4} \text { subsidy }_{i t} \\
& +\sum \beta_{i} \text { Controls }_{i t}+\xi_{i t} \\
& N E D I F_{i t}=\alpha+\beta_{1} P O S_{i t}+\beta_{2} M E D_{i t}+\beta_{3} N E G_{i t}+\beta_{4} \text { subsidy }_{i t} \\
& +\sum \beta_{i} \text { Controls }_{i t}+\xi_{i t}
\end{aligned}
$$

As shown in Table 4, the main explained variables Adj_EDI, EDIF and NEDIF were close in mean value. The mean EDIF was slightly lower than that of the other two variables, indicating that the sample enterprises should improve the EDIF and quantify their environmental behaviors.

In terms of media reports, the mean numbers of positive reports and neutral reports was far larger than the mean number of negative reports, but the number of reports varied greatly from enterprise to enterprise. It can be seen that, with the growth in government regulation and corporate environmental awareness, the sample enterprises have reduced the number of environmental accidents and ramped up environmental investment.

As shown in Table 5, the coefficient of POS number was estimated by model (4) as 0.251 , which is significant at the $5 \%$ level. Obviously, the Adj_EDI increases with the number of POS. After all, government subsidies and social images greatly motivate the enterprises to protect the environment.
The coefficients of POS number estimated by models (5) and (6) were also positive, but only significant at the $10 \%$ level. The results show that positive reports have basically the same promoting effect on EDIF and NEDIF.

The coefficients of NEU number were of low significance in all three models. This means neutral reports have an insignificant impact on corporate environmental disclosure.

The coefficients of NEG number were estimated as -0.415 , -0.0218 and -0.0288 by models (4)-(6), respectively, which were significant at the levels of $1 \%, 5 \%$ and $10 \%$, respectively. Therefore, the number of negative reports has a significantly negative correlation with corporate environmental disclosure. In other words, negative reports will suppress the enterprises. To evade environmental risks, the enterprises will be cautious and conservative about environmental disclosure.

Moreover, the coefficients of government subsidies estimated by the three models were positive, and significant at the levels of $1 \%, 5 \%$ and $10 \%$, respectively. Hence,

\begin{tabular}{|c|c|c|c|}
\hline Variable & $\begin{array}{l}\text { Model (4) } \\
\text { Adj_EDI }\end{array}$ & $\begin{array}{c}\text { Model (5) } \\
\text { EDIF }\end{array}$ & $\begin{array}{c}\text { Model (6) } \\
\text { NEDIF }\end{array}$ \\
\hline \multirow[t]{2}{*}{ POS } & $0.251 * *$ & $0.0216^{*}$ & $0.0528 *$ \\
\hline & $(0.124)$ & $(0.0121)$ & $(0.0104)$ \\
\hline \multirow[t]{2}{*}{$\mathrm{NEU}$} & $0.422 *$ & 0.0179 & 0.0168 \\
\hline & $(0.223)$ & $(0.0191)$ & $(0.0139)$ \\
\hline \multirow[t]{2}{*}{ NEG } & $-0.415 * * *$ & $-0.0218^{*}$ & $-0.0288 * *$ \\
\hline & $(0.155)$ & $(0.0112)$ & $(0.0117)$ \\
\hline \multirow[t]{2}{*}{ Subsidy } & $0.255 * * *$ & $0.00485^{* *}$ & $0.00370 *$ \\
\hline & $(0.0630)$ & $(0.00400)$ & $(0.00424)$ \\
\hline \multirow[t]{2}{*}{ IDR } & -0.0789 & -0.0237 & 0.0110 \\
\hline & $(0.200)$ & $(0.0170)$ & $(0.0128)$ \\
\hline \multirow[t]{2}{*}{ BSS } & -0.0428 & $-0.00738 *$ & -0.00145 \\
\hline & $(0.0455)$ & $(0.00388)$ & $(0.00327)$ \\
\hline \multirow[t]{2}{*}{ ROE } & $-0.341 * *$ & $-0.181 * * *$ & -0.0607 \\
\hline & $(0.145)$ & $(0.0578)$ & $(0.0560)$ \\
\hline \multirow[t]{2}{*}{ LEV } & -0.698 & $-0.397 * * *$ & 0.0352 \\
\hline & $(0.705)$ & $(0.106)$ & $(0.0634)$ \\
\hline \multirow[t]{2}{*}{ Size } & $1.632 * * *$ & $0.282 * * *$ & $0.0515 * * *$ \\
\hline & $(0.226)$ & $(0.0313)$ & $(0.0103)$ \\
\hline \multirow[t]{2}{*}{ Stated-owned } & $1.829 * * *$ & 0.0521 & 0.0172 \\
\hline & $(0.707)$ & $(0.0621)$ & $(0.0250)$ \\
\hline \multirow[t]{2}{*}{ Constant } & $-29.65 * * *$ & $-5.774 * * *$ & $-0.657 * * *$ \\
\hline & $(5.067)$ & $(0.722)$ & $(0.219)$ \\
\hline Observations & 1143 & 1143 & 1143 \\
\hline Number of ID & 381 & 381 & 381 \\
\hline
\end{tabular}
government subsidies have significantly positive effects on Adj_EDI and EDIF, but have little impact on NEDIF.

Table 4. Descriptive statistics on main variables

\begin{tabular}{ccccccccc}
\hline variable & mean & p25 & p50 & p75 & min & max & sd & $\mathrm{N}$ \\
\hline Adj-EDI & 0.390 & 0.2 & 0.38 & 0.50 & 0 & 0.92 & 0.19 & 114 \\
EDIF & 0.360 & 30 & 0 & 0 & 0 & 0 & 0 & 3 \\
& & 0.2 & 0.33 & 0.50 & & 1 & 0.20 & 114 \\
& & 50 & 0 & 0 & & & 0 & 3 \\
NEDIF & 0.380 & 0.1 & 0.36 & 0.57 & 0 & 1 & 0.23 & 114 \\
& & 40 & 0 & 0 & & & 0 & 3 \\
POS & 16.89 & 6 & 14 & 38 & 0 & 59 & 92.7 & 114 \\
& & & & & & & 2 & 3 \\
NEU & 14.56 & 3 & 8 & 22 & 0 & 30 & 90.5 & 114 \\
& & & & & & & 1 & 3 \\
NEG & 7.84 & 2 & 5 & 14 & 0 & 21 & 38.3 & 114 \\
& & & & & & & 4 & 3 \\
\hline
\end{tabular}

Table 5. Results of multiple regressions 


\section{CONCLUSIONS}

Environmental pollution is a global problem. Facing severe environmental pollution, the Chinese government and the public are paying more and more attentions to environmental protection. Corporate environmental disclosure provides the government and the public with important environmental information, enabling them to effectively solve environmental problems.

Targeting A-share listed Chinese enterprises in heavypollution industries, this paper empirically explores the relationship between public attention, government subsidies and environmental disclosure, and further examines how environmental disclosure is affected by the number and preference of media reports. The main conclusions are as follows:

(1) The number of media reports, which reflects public attention, has a significant impact on corporate environmental disclosure. The public attention on an enterprise increases with the number of reports on its environmental behaviors. Under the pressure from public supervision, the enterprise will definitely improve its environmental disclosure. In terms of media preference, positive reports stimulate enterprises to actively disclose environmental behaviors.

(2) Government grants, financial subsidies and tax reductions, which are related to corporate environmental protection, have significant impacts on corporate environmental disclosure. Being a quantitative index, government subsidies directly affect the financial environmental disclosure. As the Chinese government calls for environmental protection, government subsidies will motivate enterprises to ramp up environmental investment, and devote more energy to energy-saving and emission reduction. To obtain government subsidies, the corporate management tends to make more high-quality disclosures of environmental behaviors

(3) The relationship between media reports, government subsidies and environmental disclosure is as follows: The growth of government subsidies weakens the promoting effect of media reports on corporate environmental disclosure. On the one hand, the environmental awareness of enterprises improves, as the government issues regulatory laws and subsidies; then, the enterprises will make less negative news. On the other hand, whether the media chooses to supervise corporate environmental behaviors depends on government regulation and the cost-benefit of reports: the media is reluctant to supervise the environmental behaviors of enterprises, for the cost of reports cannot be offset by benefits when government regulation is strict.

Based on the above conclusions, the authors proposed two strategies to regulate and improve corporate environmental disclosure:

(1) Give full play to the positive impact of government subsidies.

The government should issue more kinds of subsidies, and standardize the subsidy distribution. Compared with institutional constraints, government subsidies can effectively stimulate enterprises to invest more in environmental protection, and make high-quality disclosure of environmental behaviors.

(2) Further enhance the roles of news media in information transmission and public supervision.

The government should increase the publicity of environmental concepts through news media, and make full use of the exemplary role and social influence of benchmark enterprises, aiming to promote the public awareness of environmental protection and sustainable development. Motivated by positive reports, enterprises will undertake social responsibilities, and create a green and harmonious environment for shared growth, paving the way to sustainable development.

\section{ACKNOWLEDGEMENTS}

Supported by social science foundation project of educational department of Anhui province, China (No. SK2019A0598).

\section{REFERENCES}

[1] You, D., Yang, J. (2017). The analysis on evolutionary game of government environmental regulation and enterprise eco-technology innovation behavior based on the public participation. Science and Technology Management Research, 12: 1. https://doi.org/10.3969/j.issn.1000-7695.2017.12.001

[2] Zhang, G., Deng, N., Guan, X. (2019). The impact of public environmental supervision behavior and public environmental participation policy on the efficiency of industrial pollution governance. China Population, Resources and Environment, 29(1): 144-151. https://doi.org/10.12062/cpre.20180928

[3] Li, H., Fu, S., Gao, P. (2016). Media attention, carbon disclosure and corporate value. Statistical Research, 33(9): 63-69. https://doi.org/10.19343/j.cnki.111302/c.2016.09.008

[4] Wen, S.B., Zhou, L.L. (2017). The influencing mechanism of carbon disclosure on financial performance-“inverted U-shaped" moderating role of media governance. Management Review, 11: 16. https://doi.org/10.14120/j.cnki.cn11-5057/f.2017.11.016

[5] Carroll, C.E., McCombs, M. (2003). Agenda-setting effects of business news on the public's images and opinions about major corporations. Corporate Reputation Review, 6(1): 36-46. https://doi.org/10.1057/palgrave.crr.1540188

[6] Tzouvanas, P., Kizys, R., Chatziantoniou, I., Sagitova, R. (2019). Environmental and financial performance in the European manufacturing sector: an analysis of extreme tail dependency. The British Accounting Review, 100863. https://doi.org/10.1016/j.bar.2019.100863

[7] Yu, W., Ramanathan, R., Nath, P. (2017). Environmental pressures and performance: An analysis of the roles of environmental innovation strategy and marketing capability. Technological Forecasting and Social Change, 117: https://doi.org/10.1016/j.techfore.2016.12.005

[8] Shen, H.T., Feng, J. (2012). Media monitoring, government supervision, and corporate environmental disclosure. Accounting Research, 2(2): 72-78.

[9] Liu, G. (2016). An analysis of the incentive effect of tax preference and fiscal subsidy policy: An empirical study based on the information asymmetry theory. Manag World, 10: 62-71. https://doi.org/10.19744/j.cnki.111235/f.2016.10.005

[10] Shi, G., Zhou, N., Zheng, S., Zhang, Y. (2016). 
Environmental subsidy and pollution abatement: Evidence from the power industry. China Economic Quarterly, $15(4)$ : $1439-1462$ https://doi.org/10.13821/j.cnki.ceq.2016.03.07

[11] Lin, B., Luan, R. (2020). Are government subsidies effective in improving innovation efficiency? Based on the research of China's wind power industry. Science of The Total Environment, 710: 136339. https://doi.org/10.1016/j.scitotenv.2019.136339

[12] Li, R., Ramanathan, R. (2018). Exploring the relationships between different types of environmental regulations and environmental performance: Evidence from China. Journal of Cleaner Production, 196: 13291340. https://doi.org/10.1016/j.jclepro.2018.06.132

[13] Yang, Z., Peng, J., Tang, Q. (2018). Comparative study of compulsory and voluntary carbon disclosure: Experience from China's capital market. Journal of Systems \& Management, 27(3): 452-461.

[14] Sheng, Y.A.O., Min, Z.H.O.U. (2017). Disclosure of environmental information under policy change: A tradeoff between government subsidies and risks of violations. Finance and Trade Research, 7: 10. https://doi.org/10.19337/j.cnki.34-1093/f.2017.07.010

[15] Ji, X., Chen, H., Wang, D. (2019). Media coverage, government supervision and corporate environmental information disclosure. Chinese Journal of Environmental Management, 2: 44-53. https://doi.org/10.16868/j.cnki.1674-6252.2019.02.044

[16] Liu, D., Yang, K. (2019). Evolutionary game of environmental pollution control from the perspective of environmental protection supervision by news media. Chinese Journal of Environmental Management, 5: 127134. https://doi.org/10.16868/j.cnki.16746252.2019.05.127

[17] Plumlee, M., Brown, D., Hayes, R.M., Marshall, R.S. (2015). Voluntary environmental disclosure quality and firm value: Further evidence. Journal of Accounting and Public Policy, 34(4): 336-361. https://doi.org/10.1016/j.jaccpubpol.2015.04.004

[18] Chen, X., Qian, W. (2018). Effects of the new environmental protection law on the quality of companies environmental information disclosure. China Population, Resources and Environment, 28(12): 76-86. https://doi.org/10.12062/cpre.20180708

[19] Sengupta, A. (2015). Competitive investment in clean technology and uninformed green consumers. Journal of Environmental Economics and Management, 71: 125141. https://doi.org/10.1016/j.jeem.2015.03.001

[20] Cahan, S.F., Chen, C., Chen, L., Nguyen, N.H. (2015). Corporate social responsibility and media coverage. Journal of Banking \& Finance, 59: 409-422. https://doi.org/10.1016/j.jbankfin.2015.07.004

[21] Wang, X., Xu, X.D., Wang, C. (2013). Public pressure, social reputation, inside governance and firm environmental information disclosure: The evidence from Chinese listed manufacturing firms. Nankai Business Review, 16(2): 82-91. 